\title{
Munkanélküliség és az állam tértermelése Magyarországon két válságidőszakban
}

\author{
Unemployment and the production of state space in \\ Hungary in two crisis periods
}

\author{
CZIRFUSZ MÁRTON
}

CZIRFUSZ Márton: tudományos munkatárs, Közgazdaság- és Regionális Tudományi Kutatóközpont, Regionális Kutatások Intézete; 1097 Budapest, Tóth Kálmán u. 4.; czirfusz@rkk.hu; https://orcid.org/0000-0002-5118-5661

KULCSSZAVAK: tértermelés; materialista államelméletek; közmunka; Magyarország

ABSZTRAKT: A tanulmány az 1929-33-as és a 2008-as gazdasági válság során vizsgálja az állam munkahelyteremtő politikáit Magyarországon. A materialista államelméletek alapján az államot olyan gazdasági szereplőnek fogom fel, amely biztosítja a tőkefelhalmozást és a társadalmi újratermelés feltételeit. Ennek révén az állam tereket és léptékeket is termel, a tér- és léptéktermelésben pedig a válságidőszakok fordulópontot jelentenek. Mindkét válságidőszakban közös, hogy az állam aktívan igyekezett helyreállítani a tőkefelhalmozás folyamatát a gazdasági életbe való közvetlen beavatkozással, többek között a munkanélküliséget csökkentő közberuházások és a közfoglalkoztatási program segítségével. Szintén közös pont, hogy a beavatkozásoknak költségvetési korlátai voltak. Különbség, hogy az 1930-as évek közvetlen munkahelyteremtő programjai inkább a városi terekre összpontosultak, míg a 2008 utáni válság során az állam a vidéki térségekben a közfoglalkoztatási program átszervezésével igyekezett a munkanélkülieket helyben tartani és számukra a társadalmi újratermelés minimumfeltételeit biztosítani.

Az állam léptéktermelésében azonosság a két válságidőszak során, hogy a központi állam szoros pénzügyi kontrollt gyakorolt a megyei és települési szint felett: a központi állam egyedi elbírálás alapján, a központi költségvetésből finanszírozott különböző beruházásokat vagy munkahelyeket teremtő programokat. A központi állam feletti lépték a programok lehetséges finanszírozásában játszott szerepet: a külföldi kölcsönökkel újabb beruházásokat lehetett beindítani az 1930-as években, míg 2008-at követően részben az európai uniós források szolgálták a munkahelyek megőrzését.

Márton CZIRFUSZ: research fellow, Institute for Regional Studies, Centre for Economic and Regional Studies; Tóth Kálmán u. 4., H-1097 Budapest, Hungary; czirfusz@rkk.hu; https://orcid.org/ 0000-0002-5118-5661

KEYWORDS: production of space; materialist state theory; public works programme; Hungary

ABSTRACT: This article compares the job-creation policies of the Hungarian state during the crisis periods of 1929-1933 and after 2008. The theoretical basis of the study is derived from Marxist historical-materialist state theories that argue that the primary role of the state as an economic actor is to facilitate capital accumulation and social reproduction. Geographers expanded this approach by pointing out that the state produces spaces and geographical scales during the process of controlling capital accumulation. Times of crisis are important turning points in which the accumulation of capital, the role of the state, and thus the production of state spaces and

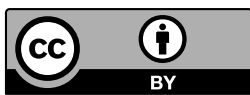


scales change significantly. Historical-materialist state theories provide a useful analytical tool to systematically understand why the state pursues job-creation programmes in times of crisis and why these programmes unfold geographically unevenly across the country.

Common points in space production during the two periods of crisis analysed are, firstly, that the state actively sought to restore capital accumulation through direct actions, including the propagation of public investment in infrastructure works (roads, water management, etc.) and the construction of public buildings (schools, hospitals, police stations, military barracks, etc.), as well as employment in the field of public works in these actions. Secondly, since financial resources were distributed unevenly, the state created geographical inequalities. Thus, most construction projects in the 1930s were concentrated in southern Hungary and Budapest, while employment in public works after the 2011 reform concentrated on small villages in the country's least developed peripheral regions. Thirdly, we can see that the state budget was too limited for measures to combat unemployment.

With regard to the production of scales, both crisis periods showed a decline in the financial autonomy of local authorities as the central government took direct control of the distribution of resources for measures against unemployment. County authorities and local governments received most of the funds allocated for specific investment purposes according to individual government decisions, differentiating them according to the lobbying forces of the municipalities. The supranational scale provided credit for the expansion of investment programmes to create jobs in the 1930s and made it possible to increase EU transfers to maintain employment after 2008.

\section{Bevezetés}

Az 1929-33-as gazdasági válság és a 2008-as gazdasági válság Magyarországon a munkanélküliség növekedését is magával hozta. Az 1930-as népszámlálás 224000 munkanélkülit írt össze Magyarország területén, a 2011-es népszámlálás 568000 főt vett számba a munkanélküliek csoportjában (az adatok a számbavétel különbözöségei miatt közvetlenül nem összehasonlíthatók) (Központi Statisztikai Hivatal 2014; Magyar Királyi Központi Statisztikai Hivatal 1941). A központi és helyi állam a munkanélküliség problematikájára többféle módon reagált, így közvetlen munkahelyteremtéssel (szükség-, ínség-, közmunkaprogramok), szociálpolitikai eszközökkel (segélyezés), valamint a „piaci” munkahelyeket bővítő eszközökkel (például a termelő vállalatok vagy az építőipar számára nyújtott adókedvezményekkel, állami beruházások indításával - ahol az építési munkákat magánvállalatok végezték).

E tanulmány megközelítése szerint mindezen eszközökben közös az a cél, hogy az állam a tőkefelhalmozást fenntartsa, ennek részeként pedig segítse a munkaerő rövid távú (napi) és hosszú távú (generációs) újratermelését egy olyan időszakban, amikor a tőkefelhalmozás „normális menetében” látszólag fennakadások vannak (bár az ebben az írásban is használt marxista elemzés szerint a kapitalizmus történetében a válságok a rendszer normál működésének részei). A tanulmány értelmezési keretében az állam e tevékenységeken keresztül tereket és léptékeket is termel (Brenner 2004), azaz a gazdaságba való állami beavatkozások figyelembe veszik a meglevő földrajzi egyenlőtlenségeket és újra is termelik ezeket az egyenlötlenségeket. 
Tanulmányomban e két válságidőszakban hasonlítom össze az állam tértermelésének jellegzetességeit a munkanélküliség kezelésében. Először a tereket és léptékeket termelő állammal foglalkozom a materialista államelméletek keretében, rámutatva arra, hogy ezen elméletek szerint az állam hogyan termeli újra a kapitalizmust és annak térbeli egyenlőtlenségeit. Az empirikus részben két témán keresztül hasonlítom össze a magyar állam munkanélküliséget csökkenteni szándékozó tevékenységeit az 1929-es és a 2008-as válságot követő időszakban: egyrészt az állam által termelt terekkel, másrészt pedig az állam által termelt léptékekkel foglalkozom. A cikk fő elméleti állítása szerint az állam válságidőszakokban történő munkahelyteremtésének térbeli egyenlőtlenségeit rendszerszerűen írhatjuk le azokkal a materialista államelméletekkel, amelyek földrajzi politikai gazdaságtani (Sheppard 2011) magyarázatokat javasolnak a kapitalizmus működésmódjának megértésére.

A tanulmány elsődleges célja rámutatni arra, hogy az állam földrajzi politikai gazdaságtani elméletei hasznos kiindulópontot nyújthatnak jelenlegi és történeti gazdasági válságok megértésében, különösen pedig történeti összehasonlító vizsgálatokban. Az a kérdés, hogy az államot elméletileg hogyan ragadhatjuk meg mint a térbeli folyamatokat aktívan alakító gazdasági aktort, a hazai gazdaságföldrajzi irodalomban korábban is megjelent (lásd pl. Barta 2002), de az elmúlt évek hazai kutatásaiban hangsúlyos változás a kritikai politikai gazdaságtani elméletek beépítése a magyarázatokba (Nagy 2017). Ugyanakkor a részletes empíriák ez utóbbi megközelítésben még sok esetben hiányoznak. Így a tanulmányban nem törekedtem a két válságidőszak szisztematikus összehasonlítására, inkább a további kutatások lehetséges irányvonalait próbáltam meg kijelölni. Tehát nem próbálom meg empirikusan is teljes körüen bebizonyítani, hogy az állam a két válságidőszakban a munkahelyteremtő politikáin keresztül mekkora és milyen hatással volt a tőkefelhalmozás helyreállítására, vagy mennyiben növelte a területi egyenlőtlenségeket.

\section{A tereket és léptékeket termelő állam}

Ahhoz, hogy az állam aktív szerepét megértsük a gazdasági folyamatok irányításában a válságidőszakokban, így a munkanélküliség kezelésében, a tértermelő állam materialista államelméletekhez tartozó felfogása hasznos kiindulópontként szolgálhat. Ezért ebben a részben áttekintem a materialista államelméletek fó állításait, hangsúlyt helyezve az állam térbeliségével foglalkozó elméleti állításokra. Ezeket az államelméleteket különböző jelzőkkel illetik - például (neo)marxista, strukturalista vagy (történelmi) materialista -, amelyek egymást metsző, de nem teljesen átfedő kategóriák (lásd például Demirović 2011; Jessop 1982). A továbbiakban a materialista államelméletek kifejezést használom, amely jelenleg leginkább a német nyelvű kritikai politikatudományi irodalomban fordul elő. A térbeli szempon- 
tok a német nyelvterület kortárs írásaiban viszont legalább annyira táplálkoznak az angolszász kritikai földrajz térszemléletéből, mint a német marxista nem földrajzi hagyományból. A materialista jelző szemléletesen kifejezi azt, hogy az állam konkrét anyagi tereket és léptékeket termel, ami ennek a tanulmánynak is a fókusza.

A jelenlegi fösodorbeli materialista államelméletek materializmusa a marxi elméletre vezethető vissza (Bayertz 2016). A 19. század második felének társadalmi változása Marx számára azt a gondolkodásmódot tette fontossá, amely a társadalmi valóságból indul ki. A marxi társadalomelméletben kitüntetett szerepe van annak, hogy az emberi munka biztosítja a társadalom anyagi szükségleteit, így a társadalmi cselekvés áll a magyarázatok középpontjában. Az emberi munka sajátos termelési viszonyokba szerveződik (mint például a kapitalista termelési mód), amely az állam sajátos formáival párosul. Marx nem dolgozott ki általános államelméletet, ami a marxi és engelsi gondolatok rekonstrukciójára és továbbgondolására ösztönözte a politikafilozófusokat (Deppe 2018). Szintén kevésbé vette figyelembe az ekkori elmélet a kapitalizmus földrajzi egyenlőtlenségeit és ennek összefüggéseit az állam különböző megjelenési formáival.

Az állam materialista elméletei szerint az állam szerepe a kapitalizmusban a tőkefelhalmozás és a társadalmi újratermelés feltételeinek megteremtése, az osztályviszonyok fenntartása (Kannankulam 2018). Az államnak sajátos materialitása van (pl. intézmények, rutinok), ami társadalmi cselekvéseket hoz létre és termel újra (Belina 2013). Válságidőszakokban az államnak ez a szerepe megbillen, ekkor új követelések, új feszültségek jelentkeznek osztályok és osztályfrakciók között. A gazdasági válságok során növekvő munkanélküliség ezen újonnan jelentkező feszültségforrások egyike, amelynek megoldását és kezelését többek között az államtól várják el a különböző érdekcsoportok (pl. az államapparátushoz általában a leginkább kapcsolódó tőkés csoportok). Az empirikus részben két magyarországi válságidőszakban mutatom be, hogy ez miként történik.

A válságidőszakokban új kihívások elé állított államot a politikatudományi irodalomban a materialista államelméleti viták újabb és újabb hullámai elemezték. Az 1930-as évek válságidőszakából Antonio Gramsci hegemóniaelmélete emelkedik ki, amely bemutatja, hogy a társadalmi konfliktusok időszakában az állam miként tölt be stabilizáló szerepet, többek között az értelmiség és a civil társadalom közvetítő szerepével, valamint a tőkefelhalmozás és a politikai uralom látszólagos szétválasztásával (Belina 2013; Gramsci 1970; Kannankulam 2018).

Az 1970-es évek válsága Nyugat-Európában a materialista államelméleti viták újabb hullámát hozta magával, amelynek során többek között azt vizsgálták, hogy a nyugat-európai jóléti állam miként válik elnyomóvá, a tőkés osztály az állami intézményrendszeren és a politikai rendszeren keresztül miként gyakorol hatalmat, illetve hogy ez a felfogás nem korlátozza-e túlságosan az állam szerepét a gazdasági (a kapitalizmus újratermelését biztosító) funkcióra (Deppe 2018). Poulantzas elemzései - a harmincas és a hetvenes évek válságáról - rámutattak arra, hogy a gazdasági válságokat a politikai és az ideológiai válságokkal együtte- 
sen, azaz a kapitalizmus ellentmondásait (azon belül pedig az osztályellentmondásokat) az állam átalakulásával párhuzamosan kell vizsgálni; de e válságok között nincs egyértelmü, közvetlen megfeleltetés. Az állam a kapitalizmus különböző időszakaiban különböző módon avatkozik be a gazdaság működésébe (Poulantzas 2008). Az 1990-es években a kibontakozó neoliberalizmus, majd a 2008-as gazdasági válság a materialista (azon belül a neogramsciánus) államelméletek továbbfejlesztését hozták magukkal, foglalkoztak például a nemzetközi osztályok és osztályfrakciók elemzésével a jelenkori globális kapitalizmusban (Bohle 2012; van der Pijl 2008), és többen érveltek a hegemóniaelmélet fontossága mellett is, beleértve a kortárs magyarországi viszonyok értelmezését (Böcskei 2018; Turai 2017).

A materialista államelméletek az utóbbi években újból felfedezték az állam térbeliségének jelentőségét is, a kritikai földrajzi kutatások pedig egyre többet foglalkoznak az állammal (Belina 2013; Nagy 2017). A jelenlegi területi kutatásokban - leggyakrabban Henri Lefebvre (az 1970-es évekbeli válságidőszakban kidolgozott) tértermelés-fogalmát használva - az állam és a kapitalista tőkefelhalmozás kapcsolatával foglalkoznak. A tértermelés fogalma az utóbbi évtized hazai irodalmában is elterjedt (Berki 2015; Boros 2010; Egyed 2018; Timár 2016), így a részletek bemutatásától ebben az írásban terjedelmi okokból eltekintek. Az elmélet fontos állítása, hogy az állam - mint határokkal rendelkező területi képződmény - egyaránt megjelenik a fizikai-materiális térben és a diszkurzív térben, mindkét szempontból hatalmi viszonyként is értelmezhető (Belina 2013; Varró 2018). A tér materialitása és a hozzá kapcsolódó jelentések nem állandók, az állam materialitása mindig társadalmi cselekvés terméke, eszköze és színtere (Belina 2013). Ezt a jellegzetességet a munkanélküliséghez kapcsolódó társadalmi cselekvések példáján mutatom be a tanulmány empirikus részében.

Az állam a terek mellett földrajzi léptékeket is termel (Brenner 2004; Czirfusz, Jelinek, Berki 2018). A politikatudományi irodalom legnagyobbrészt a központi állam léptékével foglalkozik, azzal, ahogyan a kapitalista állam a tőkefelhalmozás folyamatát a központi állami (nemzetállami) keretek között támogatja (Belina 2013). A kapitalista termelési mód hetvenes évek válsága után - amit a rugalmas felhalmozás és a neoliberalizmus fogalmaival írtak le - egyre nagyobb figyelem irányult a tőkefelhalmozás globális léptékű megszerveződésére, valamint a helyi és regionális léptékek szerepének átalakulására, a különböző léptékek egymáshoz való viszonyának megváltozására és ezek hatására a kapitalizmus földrajzi egyenlőtlenségeire (Brenner 2013; Harvey 2009; Peck 2016; Swyngedouw 2004).

Az állami politikák és az állami intézmények a fenti érvelés értelmében térbelileg mindig szelektívek, azaz különböző helyeket és tereket különböző mértékben és módon érintenek. Brenner (2004) szerint a szelektivitás három elemre vezethető vissza: az állam térbeli formájára (az államiság a politikai hatalom területileg lehatárolt egységeiben szerveződik), az állam térbeli projektjeire (az állam saját intézményeit és közpolitikáit az államterület különböző helyein és 
léptékein hozza létre és hajtja végre), valamint az állam térbeli stratégiáira (az állam cselekvése konkrétan hat az államterületen belül a tőkefelhalmozás folyamatának mikéntjére). Az állam térbeli projektjeinek (az állammüködés átalakulása) és az állam térbeli stratégiáinak (ahogyan az állam a tőkefelhalmozásra hat) mint tereket és léptékeket termelő folyamatoknak analitikus szétválasztása sok esetben nem lehetséges, és ezek együttes megvalósulása, egymásra hatása a lényeges kutatási kérdés. Mindazonáltal ebben az írásban e két folyamatot két önálló részben tárgyalom, majd összekötésükre a tanulmány végén teszek kísérletet.

Az állam tehát nem a gazdaság területi folyamatainak „ellenében” ható, azokat korrigáló vagy kiegyenlítő, a piaci folyamatokkal szemben álló, területfejlesztést vagy településfejlesztést végző, technokrata szereplö, amely a spontán módon kialakuló területi egyenlőtlenségekre reagál. A tértermelés kritikai fogalma az államot a tőkefelhalmozás aktív részeseként fogja fel, amely (elsősorban) a tőke érdekében haitja végre közpolitikai intézkedéseit. Emiatt a munkanélküliség megoldását, csökkentését célzó központi vagy helyi állami intézkedések minden esetben a tőkefelhalmozás területi egyenlőtlenségeinek inherens létrehozói, céljuk a társadalmi reprodukció lehetőségfeltételeinek biztosítása. Ezek a társadalmi reprodukciót segítő intézkedések különböző formát ölthetnek: a pénzformát öltőket (segélyek, állami beruházások) könnyebben bemutathatjuk, teljes képet viszont értelemszerüen csak a nem pénzbeli formák (pl. önerős házépítés, önellátó mezőgazdaság) vizsgálatával nyerhetünk. E tanulmányban az állami beavatkozásoknak csak egy szeletével foglalkozom, részben terjedelmi korlátok, részben pedig a kutatás jelenlegi előrehaladottsága miatt.

A materialista államelméletek - a munkanélküliséget kezelő magyarországi közpolitikák szempontjából - olyan rugalmas értelmezési keretet biztosítanak, amely nem szorítja háttérbe az állam politikai-gazdasági racionalitását a magyarázatokban, mindemellett érzékeny a vizsgált történeti és földrajzi kontextusokra. Egyfelől a munkanélküliséget közvetlenül csökkentő állami munkahelyteremtő programok (amelyek hangsúlyosabbak a válságidőszakokban) alapvetően ellentmondanak a materialista államelméletek azon alaptételének, hogy az állam maga nem végez termelést annak árutermelési értelmében (Belina 2013). Ahogy látni fogjuk, az 1930-as évek válságakor például az infrastruktúra-fejlesztésekkel beavatkozó állam, illetve a 2008 utáni válság kezelésében a magyarországi közmunkaprogram sok szempontból termelő tevékenységet is magában foglal, így térbeli stratégiáival új és sajátos konfliktusokat hoz létre a kapitalista felhalmozást végző gazdasági szereplők szempontjából (ezt a foáramú irodalom például piaci kiszorító hatásként tárgyalja). Másfelől a munkanélküliség kezelésében az állam léptékei közül a globális szint jelentősége kisebb vagy áttételesebb lehet, mint más közpolitikáknál, főleg a közvetlenül munkahelyeket teremtő állami beavatkozások eseteiben. A globális folyamatok az események „hátterében”, a munkanélküliséget növelő vagy csökkentő strukturális adottságokként vannak jelen, amelyek közvetve befolyásolják az állam térbeli és léptékbeli cselekvéseit. 


\section{A tőkefelhalmozás állam által létrehozott terei két válságidőszakban}

A válságidőszakokban megváltozik a terek szerepe a tőkefelhalmozásban: bizonyos térségeket a válság jobban érint, mint másokat. A két, általam vizsgált gazdasági válság során is a munkanélküliség térben egyenlőtlenül jelentkezett Magyarországon. Az 1930-as évek válságában a hivatalos statisztika alapvetően az ipari dolgozók fővárosi munkanélküliségét mérte: az 1930-as népszámlálás által összeírt 224000 munkanélküli közül 71000 fö (azaz 31,7\%) Budapesten volt (Magyar Királyi Központi Statisztikai Hivatal 1941; Szigeti 1935). Ugyanakkor az adatok alulbecslik a mezőgazdasági munkások körében tapasztalható munkanélküliséget: a teljesen vagy részlegesen (kevesebb munkalehetőséghez jutó) munkanélküliek száma az agráriumban a válság éveiben elérte a 600 ezer főt (Berend T., Szuhay 1978). A mezőgazdasági munkanélküliség a 30-as években csak lassan mérséklődött; a mezőgazdasági munkabérek csökkentek, és akik munkához jutottak, azok sem dolgoztak folyamatosan (Berend T., Ránki 1973). A 2011-es népszámlálás adatai alapján az 568,5 ezer munkanélküli közül 90,4 ezer fö (15,9\%) volt budapesti lakos (Központi Statisztikai Hivatal 2014), a válság a „fejlettebb”, a külföldi működő tőke által dominált ipari térségekben jelentkezett hamarabb és nagyobb mértékben. A közmunkát végzők számára az állam alacsonyan (a minimálbérnél rosszabban) fizetett munkát teremtett, 2011-ben jelentős arányban részmunkaidős foglalkoztatásban (ezt a rövid időtartamú, négyórás közfoglalkoztatást később kivezették) (Czirfusz 2014).

A munkanélküliség lefutása a két válságidőszakban hasonló volt (1. ábra). A két munkanélküli-statisztika az abszolút számokat tekintve nem hasonlítható össze egymással közvetlenül (az 1930-as évek adatai a szervezett munkásság körében mutatják a munkanélküliséget, míg a 2000-es évek értékei a Nemzetközi Munkaügyi Hivatal módszertana szerint készült KSH-adatok), a bázisindexek viszont szemléletesen mutatják a válságok párhuzamosságait. A korábbi vizsgált időszakban az 1931/32-es pénzügyi év volt a munkanélküliséget csökkentő közpolitikai intézkedések és a munkanélküliség csúcséve (1932-től Gömbös Gyula kormányával alapvetően megváltoztak a kormányzati politikák: lásd pl. Vonyó 2011; illetve az 1930/32-es években alkalmazott leginkább a kormányzat anticiklikus közmunkaprogramokat: Macher 2019). A későbbi vizsgált korszakban, 2011-től, a közmunkaprogram új rendszere miatt stagnált a munkanélküliség az adatok alapján. Mindkét válságot konjunktúra-időszak zárta le.

Az állam tértermelésének megértéséhez a válságkezelő politikák területi elemzése adhat kiindulópontot. Elméleti probléma, hogy nehezen tudjuk meghatározni, mely közpolitikák köthetők kifejezetten a válsághoz, mely közpolitikák és hogyan hatnak kifejezetten a munkanélküliség csökkentésére, illetve melyeket gondolják el kifejezetten térbeli politikaként a döntéshozók. Az 1930-as évek válsága során a központi állam és a helyhatóságok különböző segélyek nyújtásával, szükség- és ínségmunkák megszervezésével, finanszírozásával és a közberuházások növelésével próbáltak a növekvő munkanélküliség ellenében hatni (részlete- 
1. ábra: A munkanélküliek számának bázisindexei két válságidőszakban Number of unemployed people in two crisis periods (base year $=100$ )

250

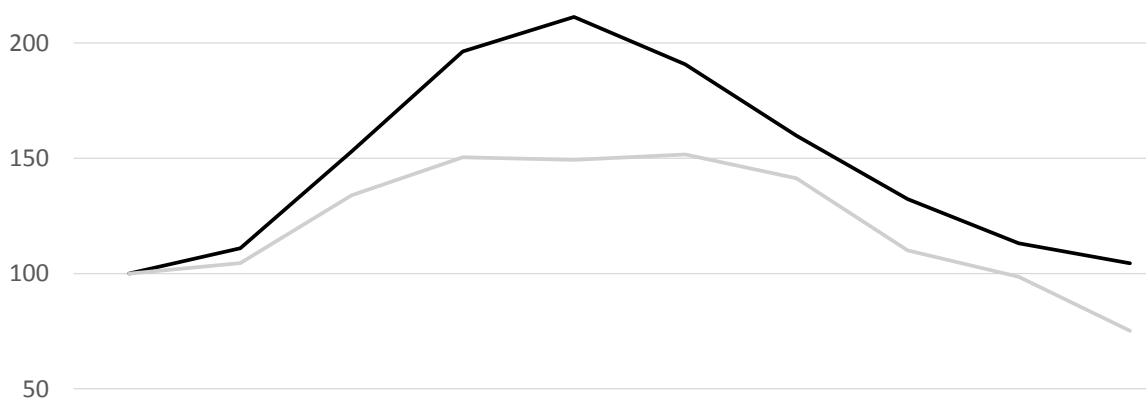

0

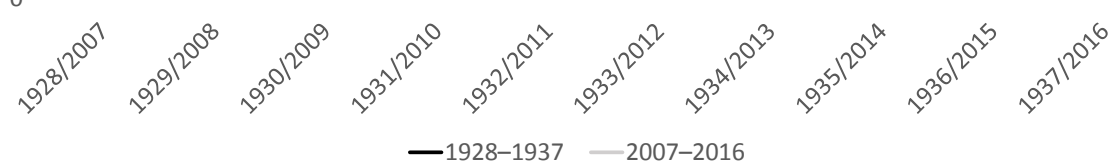

Adatok forrása: a Magyar Statisztikai Évkönyv kötetei.

sebben lásd Gyáni 2011); a 2000-es évek válsága során a közmunkaprogram bővítése (majd 2011 utáni teljes újjászervezése) és a vállalatok számára nyújtott, munkahelyteremtést is támogató stratégiai megállapodások (Merényi 2019) voltak a legfontosabb intézkedések.

Az 1930-as évekből elsőként a központi költségvetés zárszámadásaiból származó adatokat mutatom be (a zárszámadások a https://library.hungaricana.hu/hu/ collection/allami_zarszamadas/ oldalon online is hozzáférhetők). Mindazokat az állami kiadásokat figyelembe vettem az 1929/30-as és az 1934/35-ös pénzügyi év között, amelyeknél az indoklásban a munkanélküliség enyhítésének célját jelölték meg. A válságkezelés csúcsán, 1931/32-ben az összes állami közigazgatási kiadás 1,4\%-át, 13,4 millió pengőt fordítottak a munkanélküliség enyhítésére, az ezt övező években szintén meghaladták a ráfordítások a 0,5\%-ot; de ezeken felül is számos közberuházást végeztetett az állam a munkanélküliségre való hivatkozás nélkül.

Részletesen az 1930/31-es és az 1931/32-es pénzügyi év adatait vizsgáltam, mert ezeknél lehetett a ráfordításokat leginkább a földrajzi térhez rendelni (1932/33-tól a segélyezések és az útépítések eseteiben hivatkozott a zárszámadás a munkanélküliségre, ezeket viszont nem lehetett vármegyékhez vagy helyhatóságokhoz rendelni az általam vizsgált forrás alapján). Az 1930/31-es évben felaprózott szerkezetben támogattak kisebb-nagyobb beruházásokat (ezek közül kiemelkedtek a zárszámadásból földrajzilag nem beazonosítható útépítések, víz- 
szabályozási munkák, törvényhatóságoknak közmunkákra adott államsegélyek), míg 1931/32-ben segélyezésekre (8,3 millió pengo", ezek egy részét a főváros, más részét törvényhatóságok és vármegyék kapták, nem konkrét beruházásra), útépítésekre, vízszabályozási munkákra és laktanyaépítésekre fordították. Az összesítésben nem vettem figyelembe a kölcsönöket, amelyeket a törvényhatóságoknak nyújtottak különböző közberuházásokhoz (ezeknél az indoklásban ritkán szerepel a munkanélküliségre való hivatkozás, de nyilvánvalóan közrejátszott bennük a gazdasági válság ellenében ható gazdaságpolitikai szándék) vagy a hitel típusú, egyéneknek nyújtott segélyezési programokat.

A két vizsgált évben a kiadások $62 \%$-át lehetett egyértelműen földrajzi helyhez rendelni, az eredményeket a 2. ábra mutatja be. A földrajzilag beazonosítható források 43\%-a jutott Budapestre, ezen belül is kiemelkedett az 1931/32-es évben segélyezésre a székesfóvárosnak juttatott 5,2 millió pengő (felhasználásának mikéntjéről viszont a zárszámadás nem nyújt információt). A kiadások jelentős része áramlott Dél-Magyarországra, a Dunántúl alulreprezentált volt a források elosztásában, számos megye városai és községei a konkrét célokra elkülönített források elosztásából teljes mértékben kimaradtak; így az állam aktívan termelte a tőkefelhalmozás tereit beruházási politikájával. A beruházások egy része városi intézményfejlesztés volt, a vidéki térségekben a vízrendezési munkák voltak jelentősek, az útépítések pedig az elérhetőség javításával közvetlenül és közvetve, hosszú távon változtattak a tőkefelhalmozás térbeliségén. Azt, hogy mindezzel

2. ábra: A munkanélküliséget enyhítő közmunkák földrajzi megoszlása az 1930/31 és az 1931/32-es pénzügyi évben (pengő)

Geographical distribution of public works for tackling unemployment in financial years

1930/31 and 1931/32 (in Hungarian pengö)

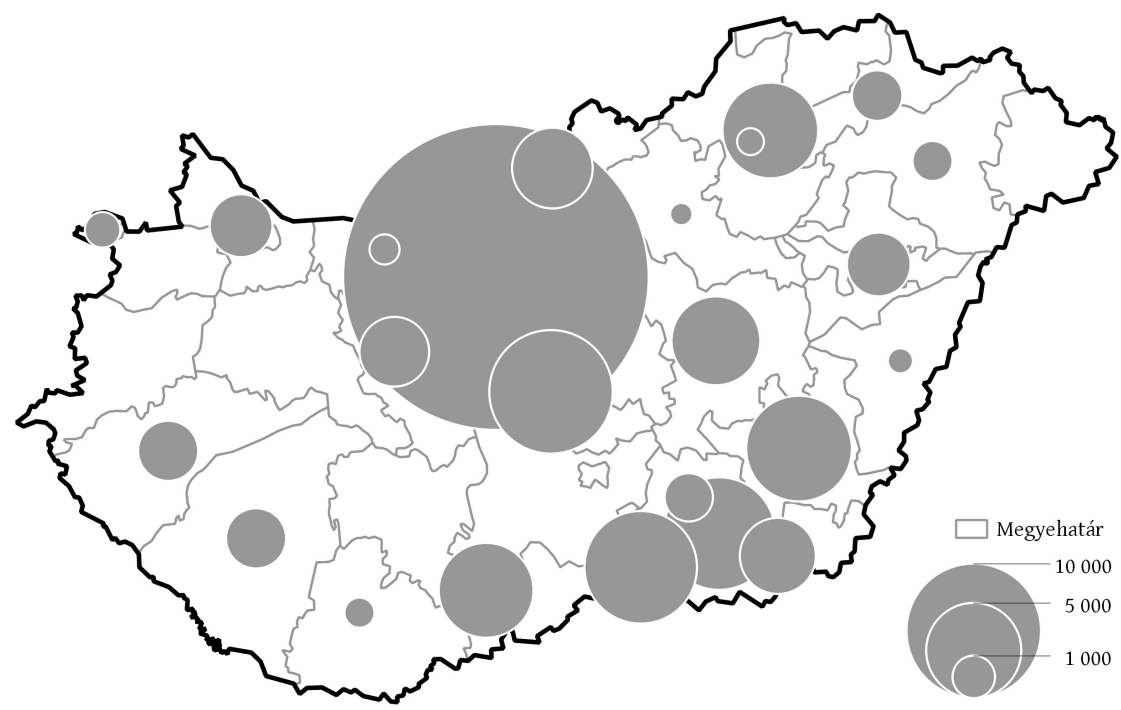

Adatok forrása: Magyar Királyi Legföbb Állami Számvevőszék 1932, 1933. 
összefüggésben a léptékek viszonyát mindezek a beruházások hogyan befolyásolták, a következő részben mutatom be.

A 2008-as válság során a növekvő munkanélküliség átmeneti kezelésére az egymást követő kormányok számos intézkedést dolgoztak ki, melyek közül a 2011-től átalakított közfoglalkoztatási programot vizsgálom részletesen. Bár a közfoglalkoztatás ekkor kialakított új rendszere számos célt tüzött ki a munkahelyteremtés mellett (pl. településfejlesztés, szociális és társadalmi célok - összefoglalásukról lásd Koltai 2018), a kormány szerint a „közfoglalkoztatási intézményrendszer legfontosabb feladata a tartósan munka nélkül levők aktivizálása és annak megakadályozása, hogy a munkájukat újonnan elveszített álláskeresők tekintetében bekövetkezzen a munka világától való elszakadás. (...) A kormány a nagy létszámú közfoglalkoztatást átmeneti intézkedésnek tekinti, melynek a következő 2-3 évben meghatározó szerepe lesz, amíg a gazdaság élénkülésével a versenyszférában megkezdődhet a foglalkoztatás dinamikus növekedése" (Hoffmann 2013, 173-174.).

A forrásokat és keretszámokat a megyék között (és a munkanélküliek számához képest is) egyenlőtlenül osztotta el a központi állam. A 3. ábra a 2013-as adatok alapján készült, ez az év a munkanélküliségi csúcsidőszak végét jelentette, egyúttal ekkorra tisztult le a 2011 utáni megreformált közfoglalkoztatási rendszer. Az ábrán látszik a kelet-magyarországi megyék felülreprezentáltsága, egyúttal Budapest alulreprezentáltsága (az összes munkanélküli személy 8,5\%-a volt

3. ábra: A közfoglalkoztatottak havi átlagos állományi létszáma (2013) Average monthly participants in the public works programme (2013)

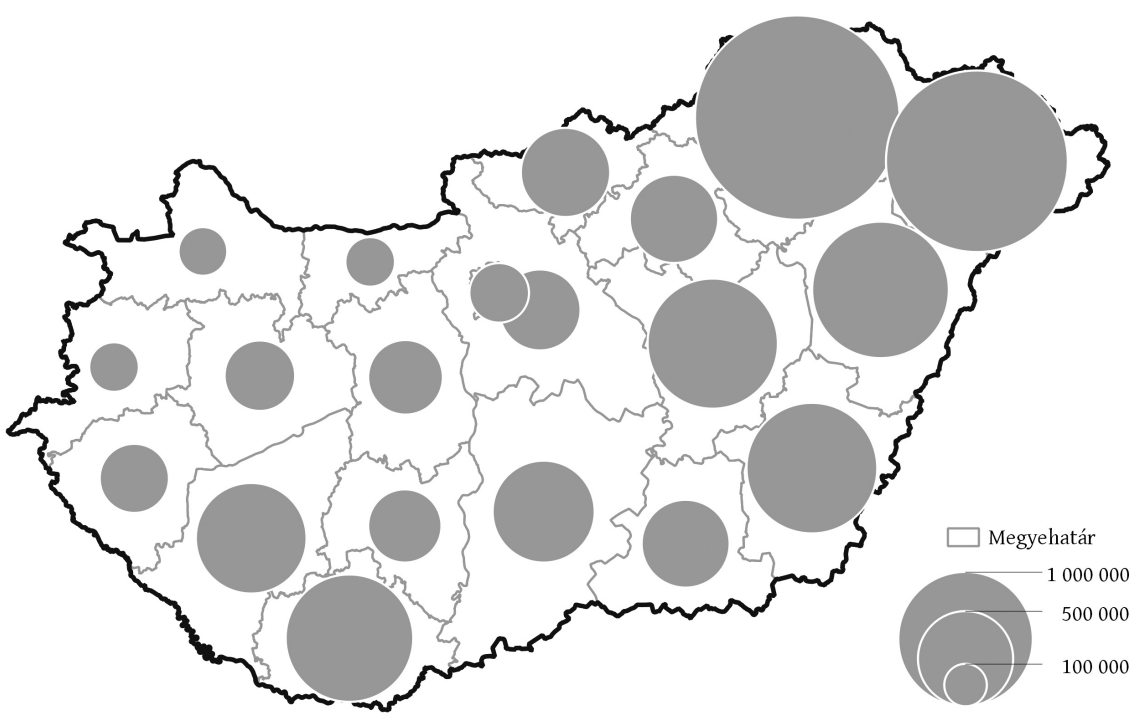

Adatok forrása: TeIR. 
budapesti, viszont csak a közfoglalkoztatottak 1,7\%-a dolgozott itt). A megyéknél is jelentősebbek voltak a megyéken belüli és a településméret szerinti egyenlőtlenségek (részletes számításokról lásd Czirfusz 2014). A közfoglalkoztatási program így alapvetően Kelet-Magyarországot és kistelepüléseket megcélzó („vidéki”) intézkedés.

A közmunka is (mint minden munka) értéket termel, így hozzájárul a tőkefelhalmozáshoz, tereket és térbeli egyenlőtlenségeket hoz létre. A közfoglalkoztatási programok területi egyenlőtlenségekre gyakorolt hatásáról szóló tanulmányok közel egyöntetű álítása szerint a közfoglalkoztatás maga is területileg egyenlőtlenül van elosztva, illetve a közfoglalkoztatás rendszere közvetlenül és közvetve növelheti a területi különbségeket (Czirfusz 2014; Molnár, Bazsalya, Bódis 2018). A településeken (főleg a mezőgazdasági Start-mintaprogramoknak köszönhetően) termelő kapacitások épültek ki, az úgynevezett hosszabb közfoglalkoztatásban is eszközbeszerzések történtek, amelyek közvetlenül a tőkefelhalmozásba való állami beavatkozást jelentenek (hiszen konkrét termelő tevékenység végezhető velük, amely sok esetben áruként vagy árukat kiváltó szerepben jelenik meg). Kérdés ugyanakkor, hogy mennyiben vált ki a közfoglalkoztatás más keretekben történő értéktermelést, milyen térbeli gazdasági viszonyokat alakít át. Például a településüzemeltetést az önkormányzatok nem saját forrásból, hanem közfoglalkoztatás keretében végeztetik, az iskolai konyha nem a piacról szerzi be az alapanyagokat, hanem a Start-mintaprogramban megtermelt élelmiszereket veszi át, a magángazdaságban kiszorító hatást is tapasztalnak egyes kutatások (ezekről lásd Koltai 2018; Koós 2016; Molnár, Bazsalya, Bódis 2018). Ezek pontos értékelése további adalékokkal szolgálhat az állam tőkefelhalmozásban játszott szerepéről.

\section{Változó állami léptékek két válságidőszakban}

A válságidőszakokban a földrajzi léptékek szerepe és egymáshoz való viszonya megváltozik, amelyre az állami politikák is hatnak, párhuzamosan azzal, ahogyan az állam tereket termel. Ebben a részben a két válságidőszakban vizsgálom a központi állam, a helyi állam (helyhatóságok, helyi önkormányzatok) és a központi állam feletti lépték szerepét a válságkezelés közvetítésében.

Az 1930-as évek válsága során a központi állam a közmunkák elosztásával aktívan befolyásolta a helyi önkormányzatok léptékének szerepét, valamint az egyes törvényhatóságok viszonyát egymáshoz képest. Szembetűnő a zárszámadások elemzésekor, hogy a legkülönbözőbb beruházásokat mint rendkívüli kiadásokat indokolták azzal, hogy a munkanélküliséget az adott településen enyhíteni kellett, ám ez az ok feltehetően a költségvetésben szereplő más beruházásra is igaz volt, illetve a munkanélküliség ténye más helyeken és más beruházások esetében is igaz lett volna. A költségvetés címrendjében ezek a tételek önálló soron 
szerepeltek, néhol az általános megfogalmazások az indoklás alapján konkrét beruházásokat takarnak. Például: „325. tétel. 2. cím: Királyi bíróságok. Törvénykezési és járásbírósági épületek és bírósági fogházak építésére, bővítésére, telek vételekre, első felszerelésekre és az ezekkel kapcsolatos költségekre. Túlkiadás 19462 P 62 f. A túlkiadást az okozta, hogy Csongrádon a munkanélküliség enyhítése érdekében közmunkát kellett végeztetni s minthogy ott egy új járásbírósági épület építése amúgy is tervbe volt véve, minisztertanácsi határozat alapján az építkezés megtörtént." (Magyar Királyi Legfőbb Állami Számvevőszék 1933, 124.). A címrendben tehát egy általános, többes számban megfogalmazott célt neveztek meg, amelyben viszont csak egyetlen város egyetlen építkezési tevékenysége szerepel. Ezt a gyakorlatot 1932 után a költségvetés alig alkalmazta; az állami beruházásoknál a munkanélküliség enyhítésére való hivatkozás lényegében megszünt (ettől függetlenül egyedi beruházásokról szóló döntések továbbra is születtek). Természetesen az állam e térbelileg szelektív, a helyi léptéken egyenlőtlenségeket termelő politikájának voltak nyertes települései: például Hódmezővásárhely a két vizsgált évben (kórház-, rendőrség-, iskola-, laktanyaépítés, vasútállomás-bővítés, háziipar támogatása, belvízrendezés, fásítás) legalább 8 különböző soron kapott támogatást (emellett feltehetően az „általános” törvényhatósági segélyezési soron is jutott forrásokhoz).

Az 1930 és 1933 közötti három pénzügyi évben folyamatosan változott a források decentralizáltságának mikéntje és mértéke. Az 1930/31-es évben a vizsgált források 80\%-át decentralizáltan költötték el (konkrét célhoz, feladathoz kötve), 14\%-ot a központi állam szervei használtak fel dekoncentrált módon (pl. iskolaépítés, légügyi hivatal Debrecenben és Nyíregyházán), 6\%-át pedig állami vállalatok kapták (pl. konkrét helyszíneken vasútállomás-építés). Ezzel szemben 1931/32-ben a munkanélküliség enyhítését célzó segélyezések decentralizált része volt $60 \%$ (ennek keretében élelmet, ruhát osztottak és szükségmunkákat végeztettek a törvényhatóságok és a vármegyék), a konkrét célhoz kötött decentralizált (a törvényhatóságoknak, megyéknek, dekoncentrált szerveknek pl. vízitársulatok) juttatott források $16 \%$-ot tettek ki, hasonlóan a központi állam szervei által felhasznált forrásokhoz. 1932/33-ban a munkanélküliség enyhítését célzó segélyezések (nagy részüket a törvényhatóságok és vármegyék használták fel), valamint a vármegyéknek és törvényhatóságoknak továbbosztott útépítési források adták a kiadások kb. fele-felét.

Kérdésként merülhet fel, hogy az állami programok mekkora súlyt képeznek a helyhatóságok által saját forrásból végrehajtott ínségkezeléshez képest. Az 1931/32-es évben az általam a zárszámadásból kigyüjtött összes, a munkanélküliséget enyhítő állami kiadás 13,4 millió pengőt tett ki. Ugyanebben az évben a székesfövárosnak a Közjótékonyság és szociálpolitika soron 15,7 millió pengő kiadása volt, a Szegényügy és népjólét kiadási soron a törvényhatósági jogú és a megyei városok 2,1-2,1, a községek 2,0 millió pengőt költöttek (Inántsy-Pap 1937, 50.). A városok 1932-ben a központi államot kérték a munkanélküliség enyhítését szol- 
gáló költségek biztosítására és egységes program végrehajtására, mert a helyhatóságoknak erre nem volt elegendő forrásuk (Inántsy-Papp 1940). Pontosabb adatokkal szolgál Inántsy-Pap (1937) az 1935/36-os évre vonatkozóan. A városokban a 6,9 millió pengős ínségszükségletből a központi állam 2,2 milliót finanszírozott (2,2 millió pengő volt a saját forrás, 2,5 millió pengő pedig ínségjárulékból származott); a községekben a 3,4 millió pengős kiadási szükségletből (a tényleges kiadások ennél magasabbak voltak) 1,9 millió pengőt nyújtott a központi állam (községekben ínségjárulékot csak pénzügyminiszteri külön engedéllyel lehetett kivetni). Összehasonlításképpen: ugyanebben az évben a helyhatóságok 639,4 millió pengőt fordítottak kölcsönök törlesztésére, ebből 366,8 millió pengő esett Budapestre.

A központi állam válságkezelő források elosztásán keresztül hatalmat gyakorló szerepe a 2000-es években is megismétlődött. A közfoglalkoztatás forráselosztása, valamint a helyi önkormányzatok finanszírozásának ezzel párhuzamos átalakítása elsősorban a kistelepülések számára vezetett a központi államtól való, korábbinál nagyobb függőséghez (lásd például Pálné Kovács 2016). Emellett a mai napig jellemző, hogy egyedi települési önkormányzati kiadásokat a központi költségvetés külön soron vagy programnak álcázott egyedi döntésekkel (vö. modern városok program - Fekete 2019) fedez, amely források megszerzésében a helyi vezetők kormányt célzó lobbizása fontos szerepet játszik - még ha a munkanélküliségre való hivatkozás a legritkább esetben is fordult elő e kiadások indoklásában a válságot követően. Hasonló módon az állami költségvetés a vállalatokkal kötött stratégiai megállapodásokkal vagy a nemzetgazdasági szempontból kiemelt beruházások címkéjével közvetlenül tud hatni a helyi lépték (a gazdasági és politikai értelemben vett helyi szint) szerepére (vö. Bajmócy et al. 2016).

A központi források ilyen elosztása a lobbi mellett a „vállalkozóiság” felé tolja az önkormányzati rendszert, ahogyan az a közfoglalkoztatásban a 2009-ben indított Út a munkához programban vagy a 2011-től megreformált közfoglalkoztatásban (azon belül is főleg a Start-mintaprogramokban) történt és történik (Keller, Bódis 2012; Molnár, Bazsalya, Bódis 2018). Az elosztási mechanizmusokat nézve a közfoglalkoztatás jelenlegi rendszerében az ún. hosszabb időtartamú közfoglalkoztatás az 1930-as években a vármegyéknek és törvényhatóságoknak juttatott dekoncentrált segélyezési forrásokkal rokonítható: a hosszabb időtartamú közfoglalkoztatásnál a megyéknek osztott keretszámokat töltik fel tartalommal a megyei és járási kormányhivatalok, figyelembe véve a települési igényeket is (az elosztási mechanizmust részletesen Molnár, Bazsalya, Bódis (2018) ismerteti). A Start-mintaprogramok konkrét célra (konkrét beruházásra és foglalkoztatásra) nyújtott támogatást jelentenek, 2017-ben a ráfordítások 40,5\%-át adták (Ignits et al. 2018), az elosztásban a központi állam és a települési önkormányzat közötti tervalku döntő fontosságú. A 2017-ben a közfoglalkoztatotti ráfordítások 21,3\%-át adó országos közfoglalkoztatási program leginkább az 1930-as években a központi állam szervei által végrehajtott munkanélküliséget enyhítő intézkedéseire ha- 
sonlít. A 2017-es adatok alapján 13,5 ezer közfoglalkoztatott dolgozott vízügyi igazgatóságoknál és vízgazdálkodási társulatoknál, 4,5 ezren erdőgazdaságoknál, 2,9 ezren kulturális közfoglalkoztatottként (Nemzeti Művelődési Intézet), 2,6 ezren a rendészetben és büntetés-végrehajtásban, 1,8 ezren a Magyar Közútnál közútfenntartásban és a református szeretetszolgálatnál a szociális vagy oktatási tevékenységeket segítve (Ignits et al. 2018). A hosszabb közfoglalkoztatásra és az országos programra egyaránt igaz, hogy a közfoglalkoztatás keretében végzett számos tevékenység a települési önkormányzatok és az országos közfoglalkoztatásban részt vevő állami vállalatok és nonprofit szervezetek közfeladatai körébe tartozik, tehát a közfoglalkoztatás révén alacsony munkabérü dolgozókhoz és többletfinanszírozáshoz jutnak e munkaadók a központi költségvetésből.

A közfoglalkoztatás léptékeket termelő jellegzetessége szempontjából a központi államok feletti szint is fontos. Az 1930-as évek válsága során, a korábbi évekhez hasonlóan, a magyar gazdaságpolitikának folyamatos kapcsolata volt a Nemzetközi Munkaügyi Hivatallal (ILO) (az 1931/32-es zárszámadás például a levélforgalom megnövekedése miatt újabb tisztviselők alkalmazásáról számol be). Az ILO 1931-33-ban a kelet-európai országokban felmérte a (munkahelyteremtési célból is) tervezett közmunkákat, azok finanszírozási lehetőségeit és hatását a munkanélküliség csökkentésére, illetve igyekezett közvetítőént fellépni az e munkák finanszírozására hitelező és a hitelt felvenni kívánó országok között (International Labour Office 1935). A központi költségvetés bevételeire és a közberuházásokra fordítható összegekre a válság negatívan hatott, így kézenfekvo"nek tűnt pótlólagos forrásokat bevonni nemzetközi finanszírozáson keresztül. Ugyanakkor az államháztartás súlyos finanszírozási problémákkal küzdött, a költségvetés folyó hiányát rövid távú külföldi hitelekkel tudták csak pótolni (Ferber 1987-1988; Macher 2019).

Az értelmiségi érdekcsoportok közül például a mérnökök (erről lapjuk, a Közmunka többször beszámolt) vagy a nagyobb városok polgármesterei is amellett érveltek, hogy a kormány vegyen fel külföldi kölcsönt a szükségmunkák finanszírozására (Baksay 1987), illetve engedélyezze a törvényhatóságoknak hosszú lejáratú külföldi kölcsönök felvételét. A nemzetközi pénzpiacokról való forráshoz jutást a városok és a községek számára a központi állami szint csak a kormány hozzájárulásával tette lehetővé; a Speyer-bankház a központi állam koordinálásával a helyhatóságoknak bevételtermelő beruházásokra nyújtott kölcsönt (Fülöp 2017). A húszas évek második felének hitelboomja után (Ferber 1987-1988; Honvári 2011) a forráshoz jutás nehezebbé vált, illetve a Speyer-kölcsönök törlesztése a válság időszakában a csökkenő helyi bevételek miatt eleve nagyobb adósságterheket jelentett a helyhatóságoknak (Honvári 2004). További forrásfeltáró vizsgálatokat igényelne, hogy a városok és községek e külföldi hitelfelvételei során miként zajlottak a kormány és a helyi szint közötti tárgyalások, kinek sikerült és milyen célra pénzügyi forrásokhoz jutnia és kinek nem. 
A központi költségvetés forráshiánya és eladósodása a 2008 utáni válság során is akut problémaként merült fel. Az IMF-től és az Európai Bizottságtól hitelt vett fel a kormány 2008-ban és 2009-ben, a 2010 utáni Orbán-kormányok a hitelforrások diverzifikálásával és a hazai fizetési mérleg többletének biztosításával stabilizálták a költségvetést, a külső forrásoktól való függőség megmaradt (Éber et al. 2019). A munkanélküliség enyhítését célzó központi költségvetési források biztosítása ugyanakkor a korábbi válságtól némileg különböző módon történt. Közös vonás a helyi önkormányzatok pénzügyi mozgásterének szükítése (például csak kormányzati engedéllyel bocsáthatnak ki devizakötvényeket vagy vehetnek fel devizában hiteleket beruházásokra vagy működésre; a helyi önkormányzatok mozgásterének e korlátozását pedig az új alaptörvény 34. cikkében rögzítették). Különbség viszont, hogy a központi állam a közfoglalkoztatási programmal nagymértékủ és közvetlenül finanszírozott megoldással szolgál a helyi önkormányzatok számára, azaz a települések elvileg nem hivatkozhatnak arra, hogy a munkanélküliség enyhítésére nem áll rendelkezésre központi forrás, ezért azt külföldi források terhére kívánnák megoldani. Szintén különbség, hogy a 2008-as válságot követően a kormány részben az EU-s transzferek átcsoportosításával tudta a vállalati munkahelyeket megőrző programokat finanszírozni (Bálint, Cseres-Gergely, Scharle 2010), amelyre az 1930-as évek válsága során nyilvánvalóan nem volt lehetőség, az államközi pénzügyi rendszer és a nemzetközi szervezetek akkori rendszere miatt.

\section{Összefoglalás}

A materialista államelméletek szerint a gazdaság működésébe történő állami beavatkozások tereket és léptékeket termelnek. Válságidőszakban az állam hatása a város és a vidék tőkefelhalmozásban játszott szerepében megváltozik; egyúttal megváltoznak a helyi önkormányzatok, a központi állam szintje és a központi államok feletti szint hatalmi viszonyai és szerepkörei egymáshoz képest (az egyesült államokbeli New Deal e szerepéről lásd Walker, Brechin 2010). Ebben a tanulmányban azt mutattam be, hogy mindez miként történt Magyarországon az 1929-33-as gazdasági válság és a 2008 utáni gazdasági válság során, a munkahelyteremtő állami programokban.

A történeti összehasonlító vizsgálatoknak bár számos korlátja van - az adatforrások változnak, az adatok nem összehasonlíthatók egymással, különbözik az állam berendezkedése stb. -, a terek és léptékek termelésének összehasonlításával ugyanakkor rá lehet mutatni a változatlan és változó tényezőkre a gazdaság állam általi, munkahelyteremtéssel történő kezelésében. Szintén fontos mozzanat a munkanélküliség kapcsán, hogy a társadalmi reprodukció áruvá válásának (kommodifikálódásának) és a bérmunkaviszony kiterjedtségének hullámait hosszú időtávon, térbeli és időbeli változatosságában elemzés tárgyává tegyük, 
mégpedig az ország világgazdaságon belüli pozíciójának figyelembevételével (vö. Zimmermann 2001).

Mindkét válságidőszakban közös, hogy az állam aktívan igyekezett helyreállítani a tőkefelhalmozás folyamatát a gazdasági életbe való beavatkozással. Szintén közös pont, hogy az ország félperifériás világgazdasági helyzetéből adódóan a beavatkozásoknak fiskális korlátai voltak: a pénzforrások szűkülése nem tette lehetővé tetszőleges mértékü gazdaságösztönző csomag bevezetését, vagy csak a külföld felé való eladósodás árán, amelyet a nemzetközi pénzpiacokon hozzáférhető források mértéke korlátozott. Különbséget jelent ugyanakkor, hogy a válságkezelés milyen tereket és léptékeket termelt. Az 1930-as évek közvetlen munkahelyteremtő programjai inkább a városi terekre összpontosítottak, köszönhetően nem utolsósorban a városi polgármesterek ez irányú nyomásgyakorlásának és a városi proletariátus szerveződésétől való félelemnek. A vidéki terekben pedig más eszközökkel igyekeztek a válság hatásait enyhíteni, például házépítési hitelekkel (Hámori 2004) vagy az egyébként is a községek hatáskörébe rendelt szociális segélyezéssel (Pálos 1934). A 2008 utáni válság során az állam a városi munkanélküliség kérdését alapvetően a gazdaság gyors helyreállításával gondolta orvosolni, a hátrányos helyzetü falusi térségekben pedig a közfoglalkoztatási program 2011 utáni átszervezésével igyekezett a munkanélkülieket helyben tartani - a segélyezési rendszer átalakításával, munkavégzéshez kötve a minimális szintü létfenntartást (Cseres-Gergely, Molnár 2014).

A válságkezelési munkahelyteremtő források egyenlőtlen elosztásának empirikus vizsgálata elméleti kérdéseket is felvet. A források egyenlőtlen elosztását vajon olyan problémának tekintjük-e, amelyet a társadalmi igazságosság szempontjából elvetendőnek tartunk? Egyáltalán mit tekintünk egyenlőtlen elosztásnak? Az egyik kérdéskör az, hogy a központi állam milyen elvek alapján osztja el területileg a válságkezelő forrásokat, miért oda jutnak a források, ahova. Ebből a szempontból bizonyos rendszerszerűségeket láthatunk (például Start-mintaprogramok a 2011 utáni közfoglalkoztatási programokban csak a hátrányos helyzetű járásokban és településeken indíthatók). Ez a tőkefelhalmozás területi egyenlőtlenségeire adott olyan állami válasz, amely szolgálhatná a területi egyenlőtlenségek csökkentését - bár az eredmény végül nem ez lett. A vállalatoknak 2008 után nyújtott munkahelyteremtő egyedi állami támogatások elosztásában vagy az 1929-33-as válság során a törvényhatóságoknak egyedi beruházási célokra nyújtott központi állami támogatásokban viszont már kevesebb tervszerűséget és rendszerszerűséget találhatunk. Ebben az esetben megmutatkozik, hogy a tőkefelhalmozást támogató állam hatalmi viszony, amely bizonyos érdekeket bizonyos módokon mozdít előre, míg más érdekeket nem hagy érvényesülni. Utóbbi körbe tartoznak például a jelenleg háttérbe szorított aktív munkaerőpiaci eszközök vagy a társadalmi egyenlőtlenségeket hosszú távon csökkenteni képes oktatásba való befektetés (amely viszont rövid távon kivonja a munkaerőt az értéktermelésből). 
A másik kérdéskör a munkanélküliséget enyhítő állami támogatásokhoz és programokhoz való hozzáférés. A munkanélküli normatív ellátások (munkanélküli segély) a két válságidőszakban mérsékeltek voltak vagy egyáltalán nem léteztek, a munkanélküli tömegek más állami programokra voltak rászorulva. Mindkét válságidőszakban igaz volt, hogy a hozzáféréssel kapcsolatosan kritikák jelentek meg: az 1930-as években a törvényhatóságok által szervezett közmunkák sokszor csak a helyi lakosoknak voltak hozzáférhetők, ami kifejezetten Budapest esetében vezetett feszültségekhez (a Budapestre beingázó vagy a válság miatt a budapesti lakhatásból kiszoruló munkanélküli tömegek például nem fértek hozzá a székesfőváros által 1932-ben kezdeményezett ínségmunkákhoz). A 2008 utáni válság közfoglalkoztatási programjaiban is sok függ a települési önkormányzatoktól és azok vezetőitől: egyrészt abból a szempontból, hogy mekkora közfoglalkoztatotti létszám van egyáltalán, másrészt hogy ezeket a helyeket a döntéshozók hogyan osztják el a rászorultak között (melyik munkanélküli lesz közmunkás, melyik nem).

Előbbiek értelmében az állam által finanszírozott közmunkák tőkefelhalmozás felől való vizsgálata szükségessé teszi a munkásokra fókuszáló kutatásokat is, hiszen a munkásság és az állam viszonya az állami foglalkoztatásban és az állami munkahelyteremtés során eltér attól, mint amelyet a „szokványos” tőke-munka viszonyban látunk (vö. Jordhus-Lier 2012). Továbbá a közfoglalkoztatottakban, az ínség- és szükségmunkásokban, az állami közberuházásokon dolgozókban az állam osztálypolitikája is leképeződik, ahol az állam célja a városi ipari proletariátus vagy a vidéki alsóbb osztályok pacifikálása (Kovai 2016; Szőke 2015). Ezek a politikák a tér- és léptéktermelés módját és folyamatát, a terek és léptékek egymáshoz való viszonyát is megváltoztatják. A történeti összehasonlító vizsgálatok ezeknek a konkrét mechanizmusoknak a megértésében lehetnek segítségünkre, mint ahogy ebben a tanulmányban bemutattam.

\section{Köszönetnyilvánítás}

A kutatás a Nemzeti Kutatási Fejlesztési és Innovációs Alap PD_16 pályázati programjának finanszírozásában valósult meg (szerződésszám: 120798).

\section{Irodalom}

Bajmócy Z., Gébert J., Elekes Z., Páli-Dombi J. (2016): Beszélünk a részvételről... Megyei jogú városok fejlesztési dokumentumainak elemzése az érintettek részvételének aspektusából. Tér és Társadalom, 2., 45-62. https://doi.org/10.17649/tet.30.2.2753

Baksay Z. (1987): A munkanélküliség felszámolására irányuló hatósági elképzelések és intézkedések az ellenforradalmi Magyarországon. Századok, 6., 1119-1175. 
Bálint M., Cseres-Gergely Zs., Scharle Á. (2010): A magyarországi munkapiac 2009-2010-ben. In: Fazekas K., Molnár Gy. (szerk.): Munkaeröpiaci tükör 2010. MTA Közgazdaságtudományi Intézet, Országos Foglalkoztatási Közalapítvány, Budapest, 15-36.

Barta Gy. (2002): A magyar ipar területi folyamatai 1945-2000. Dialóg Campus Kiadó, Budapest, Pécs

Bayertz, K. (2016): Historischer Materialismus. In: Quante, M., Schweikard, D. P. (Hrsg.): Marx-Handbuch. Leben-Werk-Wirkung. J. B. Metzler Verlag, Stuttgart, 194-208.

Belina, B. (2013): Staat und Raum im Anschluss an Marx. Positionen in Radical Geography und Materialistischer Staatstheorie. In: Belina, B. (Hrsg.): Staat und Raum. Franz Steiner Verlag, Stuttgart, 161-185.

Berend T. I., Ránki Gy. (1973): A magyar társadalom a két világháború között. In: Berend T. I., Ránki Gy. (1974): Gazdaság és társadalom. Tanulmányok hazánk és Kelet-Európa XIX-XX. századi történetéről. Magvető Kiadó, Budapest, 319-367.

Berend T. I., Szuhay M. (1978): A tókés gazdaság története Magyarországon 1848-1944. 3. kiadás. Kossuth Könyvkiadó, KJK, Budapest

Berki M. (2015): A térbeliség trialektikája. Tér és Társadalom, 2., 3-18. https://doi.org/10.17649/tet. 29.2.2658

Bohle, D. (2012): Neogramscianismus. In: Bieling, H. J., Lerch, M. (Hrsg.): Theorien der europäischen Integration. Springer VS, Wiesbaden, 165-185. https://doi.org/10.1007/978-3-531-19715-9_8

Boros L. (2010): Földrajzi alapkategóriák gazdaságföldrajzi kontextusban. In: Mészáros R., Nagy G., Nagy E., Boros L., Pál V.: A globális gazdaság földrajzi dimenziói. Akadémiai Kiadó, Budapest, 38-54.

Böcskei B. (2018): A hegemóniaelmélet Gramscitól a neoliberális gyakorlatokig. In: Antal A., Földes Gy., Kiss V. (szerk.): Marx... Interpretációk, irányzatok, iskolák. Napvilág Kiadó, Budapest, 78-92.

Brenner, N. (2004): New state spaces. Urban governance and the rescaling of statehood. Oxford University Press, Oxford

Brenner, N. (2013): A globalizáció mint területi visszaágyazódás: a városi kormányzás léptékváltása az Európai Unióban. In: Jelinek Cs., Bodnár J., Czirfusz M., Gyimesi Z. (szerk.): Kritikai városkutatás. L'Harmattan, Budapest, 182-213.

Czirfusz M. (2014): A közfoglalkoztatás térbeli egyenlőtlenségei. In: Fazekas K., Varga J. (szerk.): Munkaerőpiaci tükör 2014. MTA Közgazdaság- és Regionális Tudományi Kutatóközpont Közgazdaság-tudományi Intézet, Budapest, 126-138.

Czirfusz M., Jelinek Cs., Berki M. (2018): Marxista nézetek a térről és térbeliségről. In: Faragó L. (szerk.): Kortárs térelméletek kelet-közép-európai kontextusban. Dialóg Campus Kiadó, Budapest, 143-164.

Cseres-Gergely Zs., Molnár Gy. (2014): Közmunka, segélyezés, elsődleges és másodlagos munkaerőpiac. In: Kolosi T., Tóth I. Gy. (szerk.): Társadalmi riport 2014. TÁRKI, Budapest, 204-225.

Demirović, A. (2011): Materialist state theory and the transnationalization of the capitalist state. Antipode, 1., 38-59. https://doi.org/10.1111/j.1467-8330.2010.00810.x

Deppe, F. (2018): Der kapitalistische Staat. In: Voigt, R. (Hrsg.): Handbuch Staat. Springer VS, Wiesbaden, 485-496. https://doi.org/10.1007/978-3-658-20744-1_44

Egyed I. (2018): A tértermelés neomarxista kritikája: a technokrata térreprezentációktól a lefebvre-i városhoz való jog instrumentalizációjáig. In: Faragó L. (szerk.): Kortárs térelméletek kelet-középeurópai kontextusban. Dialóg Campus Kiadó, Budapest, 165-185.

Éber M. Á., Gagyi Á., Gerőcs T., Jelinek Cs. (2019): 2008-2018: Válság és hegemónia Magyarországon. Fordulat, 26., 28-75.

Fekete D. (2019): A Modern városok program jelentősége a hazai városfejlődésben. Tér és Társadalom, 1., 27-43. https://doi.org/10.17649/tet.33.1.3066

Ferber K. (1987-1988): Lépéshátrányban. A magyar kormány kölcsönszerzési kísérlete 1930-31-ben. Történelmi Szemle, 2., 137-154.

Fülöp T. (2017): „Erőtartalékok a nemzeti célok szolgálatában” - Az 1925. évi városi kölcsön és felhasználásának alternatívái. Hitelintézeti Szemle, 3., 119-147. https://doi.org/10.25201/HSZ. 16.3.119147

Gramsci, A. (1970): Filozófiai írások. Kossuth Könyvkiadó, Budapest

Gyáni G. (2011): Közmunka a Horthy-korban: Az állami szociálpolitika megoldási kísérletei. História, 7., 30-33. 
Hámori P. (2004): Kísérlet a magyar falu lakásügyének rendezésére a két világháború közötti Magyarországon. Az Országos Falusi Kislakásépítési Szövetkezet története. Aetas, 1., 49-73.

Harvey, D. (2009): Az „új” imperializmus: felhalmozás kisemmizés által. Fordulat, 7., 78-106.

Hoffmann I. (2013): Hoffmann Imre közfoglalkoztatási helyettes államtitkár előadása. In: Zemplényi A. (szerk.): A Munka Méltósága Projekt. Alapvető Jogok Biztosának Hivatala, Budapest. 173-179. (AJB Projektfüzetek; 2013/4.)

Honvári J. (2004): Győr és az egyesített városi kölcsönök 1925-1928. Limes, 4., 43-58.

Honvári J. (2011): 20. századi magyar gazdasági válságok. In: Katona Cs. (szerk.): Gödörböl gödörbe. Mindennemü válságok Magyarhonban a 19. és 20. században. Mediawave Közalapítvány, Vas Megyei Levéltár, Szombathely, 93-116.

Ignits Gy., Mód P., Nagy Á., Varga L. (2018): Beszámoló a 2017. évi közfoglalkoztatásról. Belügyminisztérium Közfoglalkoztatási és Vízügyi Helyettes Államtitkárság, Budapest. http://kozfoglalkoztatas.kormany.hu/download/c/7a/32000/Besz\%C3\%A1mol\%C3\%B3_2017_20180621.pdf (Letöltés: 2019. március 28.)

Inántsy-Pap E. (1937): Az önkormányzatok háztartása. Városi Szemle, 1., 1-52.

Inántsy-Papp E. (1940): A magyar városok szociálpolitikai tevékenysége. Városi Szemle, 4., 494-526., 5., 655-688., 6., 801-832.

International Labour Office (1935): Public works policy. International Labour Office, Geneva (Studies and Reports, Series C; 19.)

Jessop, B. (1982): The capitalist state. Marxist theories and methods. Martin Robertson \& Company, Oxford

Jordhus-Lier, D. C. (2012): Public sector labour geographies and the contradictions of state employment. Geography Compass, 7., 423-438. https://doi.org/10.1111/j.1749-8198.2012.00496.x

Kannankulam, J. (2018): Materialistische Staatstheorie. In: Voigt, R. (Hrsg.): Handbuch Staat. Springer VS, Wiesbaden, 199-209. https://doi.org/10.1007/978-3-658-20744-1_18

Keller J., Bódis L. (2012): Települési önkormányzatok. In: Fazekas K., Scharle Á. (szerk.): Nyugdíj, segély, közmunka. A magyar foglalkoztatáspolitika két évtizede, 1990-2010. MTA KRTK Közgazdaság-tudományi Intézet, Budapest Szakpolitikai Elemzö Intézet, Budapest, 63-76.

Koltai L. (2018) (szerk.): A közfoglalkoztatás hatása a helyi gazdaságra, helyi társadalomra. Hétfa Kutatóintézet, Budapest. http://kozfoglalkoztatas.kormany.hu/download/f/fc/42000/BM_k\%C3\%B6zfoglalkoztat\%C3\%A1s_Tanulm\%C3\%A1ny_20180928-merged.pdf (Letöltés: 2019. március 29.)

Koós B. (2016): Közfoglalkoztatás a mezőgazdaságban. Tér és Társadalom, 3., 40-62. https://doi.org/ 10.17649/tet.30.3.2793

Kovai C. (2016): Önellátó függőség: A közfoglalkoztatás társadalmi beágyazottsága egy Tolna megyei faluban. In: Kovács K. (szerk.): Földból élók. Polarizáció a magyar vidéken. Argumentum Kiadó, Budapest, 180-196.

Központi Statisztikai Hivatal (2014): 2011. évi népszámlálás. 13. A népesség gazdasági aktivitása. Központi Statisztikai Hivatal, Budapest

Macher, F. (2019): The Hungarian twin crisis of 1931. The Economic History Review, 2., 641-668. https:// doi.org/10.1111/ehr.12659

Magyar Királyi Központi Statisztikai Hivatal (1941): Az 1930. évi népszámlálás. VI. rész. Végeredmények összefoglalása, továbbá az 1935., 1938. és 1939. évi népösszeírások végeredményei. Magyar Királyi Központi Statisztikai Hivatal, Budapest (Magyar Statisztikai Közlemények Új Sorozat; 114.)

Magyar Királyi Legfőbb Állami Számvevőszék (1932): A M. Kir. Legfőbb Állami Számvevőszék jelentése a magyar államnak az 1930/31. évre vonatkozó zárszámadásáról, valamint az államháztartás vitele, az állami vagyon és az állami adósságok kezelése körül az 1930/31. évben szerzett tapasztalatairól. Budapest.

Magyar Királyi Legfőbb Állami Számvevőszék (1933): A M. Kir. Legfóbb Állami Számvevőszék jelentése a magyar államnak az 1931/32. évre vonatkozó zárszámadásáról, valamint az államháztartás vitele, az állami vagyon és az állami adósságok kezelése körül az 1931/32. évben szerzett tapasztalatairól. Budapest.

Merényi M. (2019): Hol lett munkahely a multiknak kiosztott milliárdokból? https://k.blog.hu/ 2019/01/23/ekd_terkep (Letöltés: 2019. március 26.)

Molnár Gy., Bazsalya B., Bódis L. (2018): A helyi foglalkoztatási kezdeményezések központi támogatásának elosztási mechanizmusai. MTA Közgazdaság- és Regionális Tudományi Kutatóközpont Közgazdaság-tudományi Intézet, Budapest (Műhelytanulmányok; MT-DP - 2018/27.) 
Nagy E. (2017): Az állam változó szerepe - Gazdaságföldrajzi értelmezések. Földrajzi Közlemények, 3., 226-234.

Pálné Kovács I. (2016): Modellváltás a magyar önkormányzati rendszerben. In: Jakab A., Gajduschek Gy. (szerk.): A magyar jogrendszer állapota. MTA Társadalomtudományi Kutatóközpont, Jogtudományi Intézet, Budapest, 583-599.

Pálos K. (1934): Szegénység, szegénygondozás. Martineum Nyomda, Szombathely

Peck, J. (2016): Macroeconomic geographies. Area Development and Policy, 3., 305-322. https://doi.org/ $10.1080 / 23792949.2016 .1237263$

Poulantzas, N. (2008): The political crisis and the crisis of the state. In: Martin, J. (ed.): The Poulantzas reader. Marxism, law and the state. Verso, London, New York, 294-322.

Sheppard, E. (2011): Geographical political economy. Journal of Economic Geography, 2., 319-331. https://doi.org/10.1093/jeg/lbq049

Swyngedouw, E. (2004): Globalisation or 'glocalisation'? Networks, territories and rescaling. Cambridge Review of International Affairs, 1., 25-48. https://doi.org/10.1080/0955757042000203632

Szigeti Gy. (1935): A gazdasági válság Budapest életében. Budapest Székesfőváros Statisztikai Hivatala, Budapest (Budapesti Statisztikai Közlemények; 2.)

Szőke, A. (2015): A 'Road to Work'? The reworking of deservedness, social citizenship and public work programmes in rural Hungary. Citizenship Studies, 6-7., 734-750. https://doi.org/ 10.1080/13621025.2015.1053790

Timár J. (2016): Az egyenlőtlen térbeli fejlődés - a konceptualizálás hiánya és lehetőségei. Tér és Társadalom, 3., 106-112. https://doi.org/10.17649/tet.30.3.2806

Turai E. (2017): Hogyan politizáljunk a mai Magyarországon? 5 tipp Antonio Gramscitól. Kettős Mérce, május 30. https://merce.hu/2017/05/30/hogyan_politizaljunk_a_mai_magyarorszagon_5_tipp_antonio_gramscitol/ (Letöltés: 2019. március 23.)

van der Pijl, K. (2008): A transznacionális káderosztály kétarcúsága a neoliberalizmus korában. Fordulat, 1., 69-86.

Varró K. (2018): Fókuszban a terek „politikai eredete”: a diskurzuselméleti megközelítés hozadéka a térrel kapcsolatos kutatások számára. In: Faragó L. (szerk.): Kortárs térelméletek kelet-közép-európai kontextusban. Dialóg Campus Kiadó, Budapest, 249-268.

Vonyó J. (2011): Gömbös kormánypártjának ideológiája és programja. Századok, 1., 3-38.

Walker, R. A., Brechin, G. (2010): The living New Deal: The unsung benefits of the New Deal for the United States and California. Institute for Research on Labor and Employment, University of California, Berkeley. https://escholarship.org/uc/item/6c1115sm (Letöltés: 2019. március 27.)

Zimmermann, S. (2001): Védett és védelemben nem részesülő munkaviszonyok az iparosodás korától a világgazdasági válságig. Korall, ősz-tél, 114-140. 